GARCIA, Heloise Siqueira; BONISSONI, Natammy Luana de Aguiar. A democracia participativa como instrumento de alcance do princípio da sustentabilidade. Revista Eletrônica Direito e Política, Programa de Pós-Graduação Stricto Sensu em Ciência Jurídica da UNIVALI, Itajaí, v.10, n.1, edição especial de 2015. Disponível em: www.univali.br/direitoepolitica - ISSN 1980-7791.

\title{
A DEMOCRACIA PARTICIPATIVA COMO INSTRUMENTO DE ALCANCE DO PRINCÍPIO DA SUSTENTABILIDADE
}

\author{
LA DEMOCRACIA PARTICIPATIVA COMO INSTRUMENTO DE ALCANCE DEL \\ PRINCÍPIO DE LA SOSTENIBILIDAD
}

Heloise Siqueira Garcia ${ }^{1}$

Natammy Luana de Aguiar Bonissoni²

SUMÁRIO: Introdução; 1. Ponderações introdutórias sobre a democracia; 2. Análise observativa do princípio da sustentabilidade; 3. A democracia participativa como instrumento de alcance do princípio da sustentabilidade; Considerações finais; Referências das fontes citadas .

RESUMO: O presente artigo científico possui como tema principal a busca de uma análise doutrinária entre a democracia participativa e o princípio da sustentabilidade de modo a poder demonstrar que a democracia participativa serve como instrumento de alcance do princípio da sustentabilidade. Seu objetivo geral é verificar se democracia participativa pode servir como um instrumento de alcance do princípio da sustentabilidade. Os objetivos específicos são conceituar a democracia a partir de uma evolução histórica e doutrinária de entendimentos acerca do tema; elencar as características principais do Princípio da Sustentabilidade, demonstrando seu conceito e suas dimensões a partir do entendimento de diversos doutrinadores; e analisar as conceituações básicas da democracia participativa estabelecendo uma ligação entre a mesma e a Sustentabilidade com vistas à relação com o objetivo geral proposto. Na metodologia foi utilizado o método indutivo na fase de investigação; na fase de

\footnotetext{
${ }^{1}$ Mestranda do Programa de Pós Graduação Stricto Sensu em Ciência Jurídica - PPCJ - UNIVALI. Mestranda do Máster en Derecho Ambiental y de la Sostenibilidad da Universidad de Alicante Espanha. Bolsista no Programa de Suporte à Pós-Graduação de Instituições de Ensino Particulares - PROSUP - CAPES. Graduada em Direito pela Universidade do Vale do Itajaí - UNIVALI. Advogada. Email: helo_sg@hotmail.com

2 Mestranda do Programa de Pós Graduação Stricto Sensu em Ciência Jurídica - PPCJ - UNIVALI. Bolsista no Programa de Suporte à Pós-Graduação de Instituições de Ensino Particulares - PROSUP - CAPES. Graduada em Direito pela Universidade do Vale do Itajaí - UNIVALI. Advogada. Email: natammy@hotmail.com
} 
GARCIA, Heloise Siqueira; BONISSONI, Natammy Luana de Aguiar. A democracia participativa como instrumento de alcance do princípio da sustentabilidade. Revista Eletrônica Direito e Política, Programa de Pós-Graduação Stricto Sensu em Ciência Jurídica da UNIVALI, Itajaí, v.10, n.1, edição especial de 2015. Disponível em: www.univali.br/direitoepolitica - ISSN 1980-7791.

tratamento de dados o método cartesiano e no relatório da pesquisa foi empregada a base indutiva. Foram também acionadas as técnicas do referente, da categoria, dos conceitos operacionais, da pesquisa bibliográfica e do fichamento.

Palavras-chave: Democracia; Democracia Participativa; Princípio da Sustentabilidade.

RESUMEN: El presente artículo tiene como tema principal la búsqueda de un análisis doctrinaria entre la democracia participativa y el principio de la sostenibilidad de modo a poder demonstrar que la democracia participativa sirve como instrumento de alcance del principio de la sostenibilidad. Su objetivo general es verificar se democracia participativa puede servir como un instrumento de alcance del principio de la sostenibilidad. Sus objetivos específicos son conceptuar la democracia a partir de una evolución histórica y doctrinaria de entendimientos sobre el tema; listar las características principales del Principio de la Sostenibilidad, demostrando su concepto y sus dimensiones a partir del entendimiento de diversos doctrinadores; y analizar las conceptuaciones básicas de la democracia participativa estableciendo una ligación entre la misma y la Sostenibilidad, con vistas a la relación con el objetivo general propuesto. En la metodología fue utilizado el método inductivo en la fase de investigación; en la fase de tratamiento de datos el método cartesiano y en el informe de la pesquisa fue empleada la base inductiva. Fueran también accionadas las técnicas del referente, de la categoría, de los conceptos operacionales, de la pesquisa bibliográfica y del fichamento.

Palabras-clave: Democracia; Democracia Participativa; Principio de la Sostenibilidad.

\section{INTRODUÇÃO}

A sustentabilidade ambiental está estreitamente relacionada com a democracia e sua realização irá exigir a construção de uma cultura política que promova justamente tais valores, sob uma base ecológica.

A partir deste viés ideológico é que se estabeleceu o tema central do presente artigo, que se apresenta como sendo a busca de uma análise doutrinária entre a democracia participativa e o princípio da sustentabilidade de modo a poder demonstrar que a democracia participativa serve como instrumento de alcance do princípio da sustentabilidade. 
GARCIA, Heloise Siqueira; BONISSONI, Natammy Luana de Aguiar. A democracia participativa como instrumento de alcance do princípio da sustentabilidade. Revista Eletrônica Direito e Política, Programa de Pós-Graduação Stricto Sensu em Ciência Jurídica da UNIVALI, Itajaí, v.10, n.1, edição especial de 2015. Disponível em: www.univali.br/direitoepolitica - ISSN 1980-7791.

A escolha do tema se deu a partir das discussões fomentadas no Curso de Mestrado em Ciência Jurídica da Universidade do Vale do Itajaí - UNIVALI, através de aulas e seminários com professores estrangeiros assistidos no período de agosto de 2013 a agosto de 2014, além da possibilidade proporcionada por esta última instituição em realizar estudos vinculados ao Direito Ambiental junto à Universidade de Alicante - Espanha, no mês de maio de 2014, onde ambas as autoras tiveram a oportunidade de realizar estudos junto a esta última universidade.

O desenvolvimento do artigo se dará primordialmente no âmbito do Direito Ambiental e da Teoria Política, onde se buscará analisar doutrinas de pensadores clássicos e contemporâneos que discutem a ideia da criação e evolução do conceito de democracia até o alcance do pensamento teórico atual, além de renomados doutrinadores engajados nas discussões de cunho ambiental e da sustentabilidade, foco principal do cenário mundial atual.

Por tudo isto, este artigo terá como objetivo geral VERIFICAR se democracia participativa pode servir como um instrumento de alcance do princípio da sustentabilidade. E objetivos específicos CONCEITUAR a democracia a partir de uma evolução histórica e doutrinária de entendimentos acerca do tema; ELENCAR as características principais do Princípio da Sustentabilidade, demonstrando seu conceito e suas dimensões a partir do entendimento de diversos doutrinadores; e ANALISAR as conceituações básicas da democracia participativa estabelecendo uma ligação entre a mesma e a Sustentabilidade com vistas à relação com o objetivo geral proposto.

Portanto como problemas centrais serão enfocados os seguintes questionamentos: O que é democracia e quais suas principais características? Como pode ser conceituado Princípio da Sustentabilidade e quais suas dimensões segundo as principais doutrinas atuais? No que consiste a democracia participativa e qual sua ligação com a Sustentabilidade? Pode a Democracia Participativa ser considerada como um instrumento de alcance do Princípio da Sustentabilidade?

As hipóteses da pesquisa se desenvolvem na seguinte temática: 
GARCIA, Heloise Siqueira; BONISSONI, Natammy Luana de Aguiar. A democracia participativa como instrumento de alcance do princípio da sustentabilidade. Revista Eletrônica Direito e Política, Programa de Pós-Graduação Stricto Sensu em Ciência Jurídica da UNIVALI, Itajaí, v.10, n.1, edição especial de 2015. Disponível em: www.univali.br/direitoepolitica - ISSN 1980-7791.

a) O Princípio da Sustentabilidade é um princípio de ordem fundamental e transnacional, de necessário enfoque e estudo para a possível preservação das presentes e futuras gerações.

b) A Democracia Participativa é o modelo mais abrangente de participação popular e, consequentemente, mais democrático de intervenção direta dos cidadãos nas tomas de decisões e exercício do poder do Estado.

c) A Democracia Participativa pode ser considerada como um instrumento de alcance e efetivação da sustentabilidade, pois aperfeiçoa o atual conceito de democracia direta e sua adequação às temáticas atuais, possibilitando a construção de uma cultura política fundamentada em princípios sustentáveis.

Para tanto o artigo foi dividido em três partes: a primeira denominada "Ponderações introdutórias sobre a democracia", onde se buscou explanar sobre a conceituação e evolução da ideia de democracia por filósofos e pensadores do direito; a segunda, denominada "Análise observativa do Princípio da Sustentabilidade", buscou analisar as principais características do referido Princípio da Sustentabilidade, elencando-se conceitos e ponderações de diversos doutrinadores acerca de suas dimensões; por fim, a última parte, denominada "A democracia participativa como instrumento de alcance do Princípio da Sustentabilidade", entra no cerne principal do presente artigo científico, destacando a conceptual atual da doutrina sobre o que seria a democracia participativa e qual sua relação com a Sustentabilidade, de modo a apresentar uma visão construtiva da aplicação da democracia participativa como um dos instrumentos para a efetivação do Princípio da Sustentabilidade.

Na metodologia foi utilizado o método indutivo na fase de investigação; na fase de tratamento de dados o método cartesiano e no relatório da pesquisa foi empregada a base indutiva. Foram também acionadas as técnicas do referente, da categoria, dos conceitos operacionais, da pesquisa bibliográfica e do fichamento. 
GARCIA, Heloise Siqueira; BONISSONI, Natammy Luana de Aguiar. A democracia participativa como instrumento de alcance do princípio da sustentabilidade. Revista Eletrônica Direito e Política, Programa de Pós-Graduação Stricto Sensu em Ciência Jurídica da UNIVALI, Itajaí, v.10, n.1, edição especial de 2015. Disponível em: www.univali.br/direitoepolitica - ISSN 1980-7791.

\section{PONDERAÇÕES INTRODUTÓRIAS SOBRE A DEMOCRACIA ${ }^{3}$}

Norberto Bobbio, em seu livro "O futuro da democracia"4, explicita que antes de qualquer estudo a ser realizado acerca da democracia necessário é se estabelecer um conceito mínimo da mesma, que o autor estabelece como sendo "[...] primariamente um conjunto de regras de procedimento para a formação de decisões coletivas, em que está prevista e facilitada a participação mais ampla possível dos interessados."

Já em outra obra o mesmo autor estabelece um conceito mais direto, didático e tradicionalista dos clássicos do que seria a democracia tendo por base o uso descritivo da mesma, e assim destaca:

[...] a democracia é uma das três possíveis formas de governo na tipologia em que as várias formas de governo são classificadas com base no diverso número dos governantes. Em particular, é a forma de governo na qual o poder é exercido por todo o povo, ou pelo maior número, ou por muitos, e enquanto tal se distingue da monarquia e da aristocracia, nas quais o poder é exercido, respectivamente, por um ou por poucos. ${ }^{5}$

Hans Kelsen ${ }^{6}$ já critica essa ideia de classificação tradicional das formas de governo, pois afirma que a tricotomia tradicional se mostra insuficiente, e aponta como critério de classificação o modo como a ordem jurídica é criada, baseandose na ideia de liberdade política, a partir disso afirma que "Democracia significa

\footnotetext{
${ }^{3}$ Item adaptado do capítulo publicado no livro "Direitos fundamentais e democracia III". (GARCIA, Heloise Siqueira; GARCIA, Denise Schmitt Siqueira. DEMOCRACIA E SOLIDARIEDADE: A SOLIDARIEDADE COMO INSTRUMENTO DE BUSCA DE UMA SOCIEDADE DEMOCRÁTICA. In: MACHADO, Edinilson Donisete; BERTASO, João Martins; CUNHA, Leandro Reinaldo da. (coord.) Direitos fundamentais e democracia III. Florianópolis: CONPEDI, 2014. Disponível em: <http://publicadireito.com.br/publicacao/ufsc/ficha/211.pdf>. Acesso em: 30 de setembro de 2014. p. 162/178)

${ }^{4}$ BOBBiO, Norberto. O futuro da democracia. 9. ed. Tradução de Marco Aurélio Nogueira. São Paulo: Editora Paz e Terra, 2004, p. 22.

${ }^{5}$ BOBBIO, Norberto. Estado, governo, sociedade. Para uma teoria geral da política. 10. ed. Tradução de Marco Aurélio Nogueira. São Paulo: Editora Paz e Terra, 2003, p. 137.

${ }^{6}$ KELSEN, Hans. Teoria geral do direito e do Estado. 4. ed. Tradução de Luís Carlos Borges. São Paulo: Martins Fontes, 2005. p. 406.
} 
GARCIA, Heloise Siqueira; BONISSONI, Natammy Luana de Aguiar. A democracia participativa como instrumento de alcance do princípio da sustentabilidade. Revista Eletrônica Direito e Política, Programa de Pós-Graduação Stricto Sensu em Ciência Jurídica da UNIVALI, Itajaí, v.10, n.1, edição especial de 2015. Disponível em: www.univali.br/direitoepolitica - ISSN 1980-7791.

que a 'vontade' representada na ordem jurídica do Estado é idêntica às vontades dos sujeitos. O seu oposto é a escravidão da aristocracia. ${ }^{\prime 7}$

Contudo, visando uma completa consideração do que seriam os aspectos principais da democracia, acredita-se ser importante o destaque dos principais pensamentos dos filósofos a respeito da democracia, que gerou a sua construção conceitual atual.

Norberto Bobbio ${ }^{8}$ destaca que foi o pensamento político grego que transmitiu a célebre tipologia das formas de governo, destacando a democracia como "[...] o governo dos muitos, dos mais, da maioria, ou dos pobres [...]", sendo, em suma, conforme a própria etimologia da palavra, o governo do povo.

Nesse sentido, de maneira cronológica, procurar-se-á explanar a principal ideia de alguns dos principais filósofos que propuseram discussões sobre a democracia, de modo a se poder conceber o ponto atual da conceituação da democracia.

Platão, em seu livro "A República" ${ }^{9}$, foi um dos primeiros filósofos a introduzir a ideia de distinguir as formas de governo com base no número de governantes, o que posteriormente é retomado por diversos outros filósofos, assim, o referido autor defende que seria a democracia a forma de constituição, ou forma de governo, em que o poder emana da multidão, sendo que ao decorrer do Livro VIII da obra propõe algumas discussões sobre esta forma de governo de maneira a ressaltar-Ihe suas principais qualidades e defeitos.

Já de maneira enfática dispõe o filósofo que a democracia surgiria após a vitória dos pobres, "[...] estes matam uns, expulsam outros, e partilham igualmente com os que restam o governo e as magistraturas, e esses cargos são, na maior parte, tirados à sorte. ${ }^{\prime 10}$. E continua mais a frente defendendo tal forma de

\footnotetext{
${ }^{7}$ KELSEN, Hans. Teoria geral do direito e do Estado, p. 406.

${ }^{8}$ BOBBIO, Norberto. Liberalismo e democracia. 3. ed. Tradução de Marco Aurélio Nogueira. São Paulo: Brasiliense, 1990, p. 31.

9 PLATÃO. A república. Texto integral. Tradução de Pietro Nassetti. São Paulo: Martin Claret, 2003.

${ }^{10}$ PLATÃO. A república, p. 253.
} 
GARCIA, Heloise Siqueira; BONISSONI, Natammy Luana de Aguiar. A democracia participativa como instrumento de alcance do princípio da sustentabilidade. Revista Eletrônica Direito e Política, Programa de Pós-Graduação Stricto Sensu em Ciência Jurídica da UNIVALI, Itajaí, v.10, n.1, edição especial de 2015. Disponível em: www.univali.br/direitoepolitica - ISSN 1980-7791.

governo ao ressaltar que esta seria muito capaz de ser a mais bela das formas de governo.

Ressaltando ainda, que suas principais vantagens caracterizam-se pelo fato de ser uma forma de governo aprazível, anárquica, variegada, isonômica, repartindo sua igualdade do mesmo modo pelo que é igual e pelo que é desigual. ${ }^{11}$

Seguindo seus passos em dividir as formas de governo a partir da quantidade de pessoas que o comandam, vem Aristóteles, em sua obra "Política"12, que além de estipular a divisão pelo número de governantes, apresentando três formas de governo corretas, ainda comenta sobre os três desvios dessas formas de governo, estando a democracia entre este últimos.

Nesse diapasão Aristóteles apresenta como sendo as formas corretas de governo, ou constituição, as que uma única pessoa, poucas pessoas ou muitas pessoas governam visando um interesse comum. Enquanto que os desvios dessas formas corretas são aqueles em que uma, poucas ou muitas pessoas governam segundo o interesse privado, sendo que são caracterizadas como desvios, pois os membros da Cidade, na qualidade de cidadãos, devem participar da vantagem comum. ${ }^{13}$

Assim, das formas de governo em que só um governa, a sua forma correta seria a monarquia, e o seu desvio a tirania; das formas em que uns poucos, os melhores homens, governam, a sua forma correta seria a aristocracia, e o seu desvio a oligarquia; e das formas em que grande parte dos cidadãos governam, a forma correta seria chamada pelo nome genérico de "constituição", e seu desvio democracia. ${ }^{14}$

\footnotetext{
${ }^{11}$ PLATÃO. A república, p. 255.

${ }^{12}$ ARISTÓTELES. Política. 5. ed. Texto integral. Tradução de Pedro Constantin Tolens. São Paulo: Martin Claret, 2001, p. 124-125.

${ }^{13}$ ARISTÓTELES. Política, p. 124.

${ }^{14}$ ARISTÓTELES. Política, p. 124.
} 
GARCIA, Heloise Siqueira; BONISSONI, Natammy Luana de Aguiar. A democracia participativa como instrumento de alcance do princípio da sustentabilidade. Revista Eletrônica Direito e Política, Programa de Pós-Graduação Stricto Sensu em Ciência Jurídica da UNIVALI, Itajaí, v.10, n.1, edição especial de 2015. Disponível em: www.univali.br/direitoepolitica - ISSN 1980-7791.

E finaliza o filósofo comentando que "[...] a democracia é o governo no qual se tem em mira apenas o interesse da massa $[\ldots]^{115}$, não possuindo, então, interesse de toda a sociedade.

Quase dois mil anos após a criação da ideia dos filósofos antigos John Locke publica a obra "Segundo tratado sobre o governo"16, em que propõe diversas discussões sobre o governo e a política, esclarecendo, inclusive, sua principal ideia sobre conceitos políticos importantes, como por exemplo o faz no primeiro capítulo da obra quando expõe o que entende por "poder político".

Nesse contexto, no capítulo $\mathrm{X}$, o autor apresenta o que seriam, para ele, as "formas de uma comunidade", onde não separa as formas de governo apenas pela quantidade de pessoas que as governam, como os antigos filósofos, mas conforme suas principais características quanto ao poder de legislar, e sobre a democracia comenta que

[...] desde que os homens começaram a se reunir em sociedades, a maioria de sufrágios teve naturalmente todo o poder, e pode utilizá-lo para fazer, periodicamente, leis destinadas à comunidade, leis estas executadas por funcionários por ela nomeados. Nesse caso, a forma de governo é uma perfeita democracia. ${ }^{17}$

Ainda salienta o referido filósofo que apesar de existirem as três formas básicas de governo, ou de uma comunidade, sendo elas a democracia, a oligarquia e a monarquia, é possível ainda que os cidadãos de uma determinada sociedade ainda estabeleçam formas de governo compostas ou mistas. ${ }^{18}$

Na mesma época de John Locke, Montesquieu publica seu livro "Do espírito das leis"19, onde elabora conceitos sobre formas de governo e exercícios da autoridade política que se tornaram pontos doutrinários básicos da ciência

\footnotetext{
${ }^{15}$ ARISTÓTELES. Política, p. 125.

16 LOCKE, John. Segundo tratado sobre o governo. Texto integral. Tradução de Alex Marins. São Paulo: Martin Claret, 2002.

${ }^{17}$ LOCKE, John. Segundo tratado sobre o governo, p. 88.

${ }^{18}$ LOCKE, John. Segundo tratado sobre o governo, p. 88.

19 MONTESQUIEU. Do espírito das leis. Texto integral. Tradução de Jean Melville. São Paulo: Martin Claret, 2002.
} 
GARCIA, Heloise Siqueira; BONISSONI, Natammy Luana de Aguiar. A democracia participativa como instrumento de alcance do princípio da sustentabilidade. Revista Eletrônica Direito e Política, Programa de Pós-Graduação Stricto Sensu em Ciência Jurídica da UNIVALI, Itajaí, v.10, n.1, edição especial de 2015. Disponível em: www.univali.br/direitoepolitica - ISSN 1980-7791.

política. Comentando, também, no livro segundo, onde trata das leis que derivam diretamente da natureza do governo, da natureza de três diferentes governos: republicano, monárquico e despótico, relacionando a democracia ao primeiro. $^{20}$

Comenta o filósofo que a democracia acontecerá dentro de uma república quando o povo, ao formar um só corpo, tem o poder soberano, sendo que caso esse poder estivesse nas mãos de apenas uma parte do povo tratar-se-ia de uma aristocracia. E complementa afirmando que "O povo, na democracia, é, em certos aspectos, o monarca, e, em outros aspectos, o súdito."21

Finalizando os filósofos antigos e modernos elencados para serem apresentados no presente artigo científico elenca-se Jean-Jacques Rousseau, que talvez tenha sido o filósofo que mais criticou a democracia. Jean-Jacques Rousseau viveu na mesma época iluminista de John Locke e Montesquieu, destacando-se como grande obra sua "Do contrato social"22, nesta obra o autor trata do que seria o contrato social para ele e quais seus principais aspectos, diferenciando sua ideia das de John Locke e Montesquieu, sendo que ele traz a ideia de que o homem é naturalmente bom, sendo a sociedade, instituição regida pela política, a culpada por sua "degeneração".

Rousseu $^{23}$ afirma que não haveria governo mais sujeito às guerras civis do que o democrático ou o popular, pois não haveria nenhum outro que tenha tanta tendência a frequente e continuamente mudar de forma, nem que demande mais vigilância e coragem para se manter. Foi na referida obra, também, que o autor escreve uma de suas mais famosas frases, que quase todos os autores que o seguiram, ao tratarem da democracia a citam, "Se houvesse um povo de deuses,

\footnotetext{
${ }^{20}$ MONTESQUIEU. Do espírito das leis, p. 23.

${ }^{21}$ MONTESQUIEU. Do espírito das leis, p. 23.

22 ROUSSEAU, Jean-Jacques. Do contrato social. - Dados eletrônicos. Florianópolis: UFSC Centro de filosofia e ciências humanas. Edição eletrônica: Ridendo Castigat Mores. Disponível em: <http://www.cfh.ufsc.br/ wfil/contrato.pdf> Acesso em 25 de novembro de 2013.

23 ROUSSEAU, Jean-Jacques. Do contrato social, p. 95.
} 
GARCIA, Heloise Siqueira; BONISSONI, Natammy Luana de Aguiar. A democracia participativa como instrumento de alcance do princípio da sustentabilidade. Revista Eletrônica Direito e Política, Programa de Pós-Graduação Stricto Sensu em Ciência Jurídica da UNIVALI, Itajaí, v.10, n.1, edição especial de 2015. Disponível em: www.univali.br/direitoepolitica - ISSN 1980-7791.

ele se governaria democraticamente. Tão perfeito governo não convém aos homens." 24

Salienta-se novamente a importância de ter sido elencado esses principais pensamentos dos filósofos clássicos, pois torna-se mais fácil a verificação da construção do que se entende hoje por democracia. Justamente como traz Norberto Bobbio ${ }^{25}$, ao dispor que a ideia do regime democrático, por sua essência, é o estar em transformação, "[...] a democracia é dinâmica, o despotismo é estático e sempre igual a si mesmo."

Paulo Bonavides ${ }^{26}$ comenta que nos dias atuais a democracia domina a linguagem política, o que vem ocorrendo desde o século $X X$, sendo que é raro o governo, a sociedade ou o Estado que não se proclame democrático. Entretanto ressalta o autor que, na realidade, a democracia não é nada mais que um nome debaixo de todos os abusos que a infamaram, mas que mesmo assim não deixou de ser a potente força condutora dos destinos da sociedade contemporânea, deixando de ser importante a significação que se lhe empregue.

Neste ponto, como modo que união de ideias, importante é o destaque de Paulo $\mathrm{Cruz}^{27}$, que afirma que o conceito de democracia foi se impondo progressivamente desde o século XIX de maneira a referir-se às relações entre Estado e Sociedade, deixando antever um regime de governo em que o poder político do Estado pertenceria à toda a população, ou seja, ao povo. Destacando que sua finalidade última seria o "[...] controle, intervenção e a definição, pelos cidadãos, de objetivos do poder político, cuja titularidade Ihes corresponderia em

\footnotetext{
${ }^{24}$ ROUSSEAU, Jean-Jacques. Do contrato social, p. 96.

${ }^{25}$ BOBBIO, Norberto. O futuro da democracia, p. 19.

${ }^{26}$ BONAVIDES, Paulo. Ciência política. 18. ed. São Paulo: Malheiros, 2011, p. 287.

27 CRUZ, Paulo Márcio. Democracia e cidadania. Revista Eletrônica Novos Estudos Jurídicos, ISSN Eletrônico 2175-0491, Itajaí, v. 5, n. 10, 2000. Disponível em: < http://siaiweb06.univali.br/seer/index.php/nej/article/view/1539>, p. 109.
} 
GARCIA, Heloise Siqueira; BONISSONI, Natammy Luana de Aguiar. A democracia participativa como instrumento de alcance do princípio da sustentabilidade. Revista Eletrônica Direito e Política, Programa de Pós-Graduação Stricto Sensu em Ciência Jurídica da UNIVALI, Itajaí, v.10, n.1, edição especial de 2015. Disponível em: www.univali.br/direitoepolitica - ISSN 1980-7791.

parcelas iguais, de acordo com o princípio de que o Governo deve refletir a vontade do povo, sempre com base num padrão ético determinado."28

Sendo nesse sentido que destaca Norberto Bobbio ${ }^{29}$, ao afirmar que deve-se pensar no desenvolvimento das instituições democráticas no sentido da democratização do Estado à democratização da sociedade, estabelecendo-se as relações entre Estado e Sociedade, como comentado por Paulo Cruz.

Por fim, interessante é o destaque de Arnaldo Miglino ${ }^{30}$ ao afirmar que o que caracteriza as democracias modernas é o relacionamento entre os cidadãos e as autoridades públicas, independentemente de sua esfera.

Com este breve colacionado de doutrinas pode-se então verificar algumas das características principais da democracia, ou seja, numa classificação tripartida clássica ela se enquadraria como a forma de governo em que o povo, a coletividade, os cidadãos, é que tem a titularidade do poder, caracterizando, nos tempos contemporâneos, apesar da possibilidade de percepção de diversas variações suas, pela necessária estreita relação entre Estado e Sociedade, através de vários mecanismos democráticos que não são base do presente artigo científico.

\section{ANÁLISE OBSERVATIVA DO PRINCÍPIO DA SUSTENTABILIDADE}

Antes de se adentrar diretamente no tema central do presente artigo há que se traçar algumas considerações sobre o Princípio da Sustentabilidade e a construção teórica do mesmo até a sua concepção mais atual.

O Direito Ambiental admite seu estudo a partir de vários enfoques, sendo que considerando o progresso cronológico e impulso político utilizar-se-á no presente

\footnotetext{
${ }^{28}$ CRUZ, Paulo Márcio. Democracia e cidadania. Revista Eletrônica Novos Estudos Jurídicos, ISSN Eletrônico 2175-0491, Itajaí, v. 5, n. 10, 2000. Disponível em: < http://siaiweb06.univali.br/seer/index.php/nej/article/view/1539>, p. 109.

${ }^{29}$ BOBBIO, Norberto. O futuro da democracia, p. 70.

${ }^{30}$ MIgLiNO, Arnaldo. A cor da democracia. Florianópolis: Conceito editorial, 2010, p. 110.
} 
GARCIA, Heloise Siqueira; BONISSONI, Natammy Luana de Aguiar. A democracia participativa como instrumento de alcance do princípio da sustentabilidade. Revista Eletrônica Direito e Política, Programa de Pós-Graduação Stricto Sensu em Ciência Jurídica da UNIVALI, Itajaí, v.10, n.1, edição especial de 2015. Disponível em: www.univali.br/direitoepolitica - ISSN 1980-7791.

trabalho as considerações estudadas pelo Professor Dr. Gabriel Real Ferrer ${ }^{31}$, o qual separa o progresso cronológico em "ondas" em relação às grandes Conferências Mundiais sobre o Meio Ambiente.

La visualización de la fulgurante evolución del Derecho Ambiental, admite, lógicamente, varios enfoques. Para su comprensión entiendo que deben explorarse mínimamente al menos tres, de los que dos de ellos: su progreso cronológico, al que llamaremos "olas" y su progresión técnico-jurídica, que visualizaremos como estratos, tienen que ver con su manifestación más externa o superficial y, el tercero, con su evolución conceptual y su incardinación en el sistema social actual, aspectos mucho más profundos y enjundiosos. ${ }^{32}$

Sabe-se que todas as discussões concernentes ao direito ambiental a nível mundial tiveram início nos anos 60, o que ensejou o que o referido professor optou por chamar de "primeira onda", com seu ápice na primeira conferência mundial sobre meio ambiente ocorrida em 1972 em Estocolmo, a qual permitiu a proliferação da legislação ambiental e a sua constitucionalização em diversos países.

A segunda onda se desenvolveu com a segunda conferência mundial sobre meio ambiente ocorrida em 1992, sediada na cidade do Rio de Janeiro, onde começou a haver articulações de movimentos com surgimento de organizações não governamentais (ONG's) e o aumento do número de novos agentes sociais implicados com a proteção ambiental, ademais, todos os países participantes passaram a se dotar de abundante e moderna legislação ambiental, dando lugar a uma onda de normas e possibilitando o surgimento do que o Professor Gabriel

31 Sobre o tema ver: REAL FERRER, Gabriel. La construcción del derecho ambiental. Revista Eletrônica Direito e Política, Programa de Pós-Graduação Stricto Sensu em Ciência Jurídica da UNIVALI, Itajaí, v.6, n.2, $2^{\circ}$ quadrimestre de 2011. Disponível em: <www.univali.br/direitoepolitica> - ISSN 1980-7791; REAL FERRER, Gabriel. Calidad de vida, medio ambiente, sostenibilidad y ciudadanía ¿Construimos juntos el futuro? Revista Eletrônica Novos Estudos Jurídicos, ISSN Eletrônico 2175-0491, Itajaí, v. 17, n. 3, 30 quadrimestre de 2012. Disponível em: <http://siaiweb06.univali.br/seer/index.php/nej/article/view/4202>.

32 REAL FERRER, Gabriel. La construcción del derecho ambiental. Revista Eletrônica Direito e Política, p. 477. 
GARCIA, Heloise Siqueira; BONISSONI, Natammy Luana de Aguiar. A democracia participativa como instrumento de alcance do princípio da sustentabilidade. Revista Eletrônica Direito e Política, Programa de Pós-Graduação Stricto Sensu em Ciência Jurídica da UNIVALI, Itajaí, v.10, n.1, edição especial de 2015. Disponível em: www.univali.br/direitoepolitica - ISSN 1980-7791.

Real Ferrer chamou da "geração da fotocópia"33. O grande destaque que se pode dar foram as discussões surgidas acerca das dimensões da sustentabilidade.

A terceira onda surgiu com a conferência mundial sobre o meio ambiente de 2002, ocorrida em Johannesburg, também conhecida como Rio +10 , essa sim com um enfoque muito forte no desenvolvimento sustentável. Sendo que foi nessa conferência que finalmente houve a integração das três dimensões da sustentabilidade mais doutrinariamente consideradas: a ambiental, a social e a econômica.

Entretanto, apesar de se reconhecer os avanços que propôs a Conferência, a sensação foi de fracasso e indiferença, pois se acordaram diversas metas e medidas, porém não se instauraram meios efetivos para controlar sua implementação e eficácia, não se dando nenhum passo à institucionalização de uma eficaz governança ambiental planetária, sentimento este que se estendeu até a Conferência Mundial sobre o Meio Ambiente ocorrida no ano de 2012, novamente na cidade do Rio de Janeiro, conhecida como Rio +20 , tratada como a quarta onda ${ }^{34}$.

A referida Conferência, última ocorrida, teve como objetivo reforçar o compromisso político dos Estados em relação ao desenvolvimento sustentável, identificando os progressos nos compromissos já firmados no âmbito da ONU, assim como desafios emergentes ainda não trabalhados. ${ }^{35} \mathrm{Seu}$ foco, conforme explana Ricardo Stanziola Vieira ${ }^{36}$, ateve-se a dois temas centrais: "(..) a

\footnotetext{
33 O que aconteceu foi a grande reprodução das normas umas às outras, sem se considerar qualquer realidade social, econômica, jurídica e ambiental sobre que se projetavam. Sobre o tema ver: REAL FERRER, Gabriel. La construcción del Derecho Ambiental. Revista Aranzadi de derecho ambiental, Pamplona - España, n. 1, 2002. p. 73-93.

34 REAL FERRER, Gabriel. Calidad de vida, medio ambiente, sostenibilidad y ciudadanía ¿Construimos juntos el futuro? Revista Eletrônica Novos Estudos Jurídicos. p. 318.

35 VIEIRA, Ricardo Stanziola. Rio+20 - conferência das nações unidas sobre meio ambiente e desenvolvimento: contexto, principais temas e expectativas em relação ao novo "direito da sustentabilidade". Revista Eletrônica Novos Estudos Jurídicos, ISSN Eletrônico 2175-0491, Itajaí, v. 17, n. 1, 10 quadrimestre de 2012. Disponível em: <http://siaiweb06.univali.br/seer/index.php/nej/article/view/3638> p. 50.

36 VIEIRA, Ricardo Stanziola. Rio+20 - conferência das nações unidas sobre meio ambiente e desenvolvimento: contexto, principais temas e expectativas em relação ao novo "direito da sustentabilidade". Revista Eletrônica Novos Estudos Jurídicos, p. 50.
} 
GARCIA, Heloise Siqueira; BONISSONI, Natammy Luana de Aguiar. A democracia participativa como instrumento de alcance do princípio da sustentabilidade. Revista Eletrônica Direito e Política, Programa de Pós-Graduação Stricto Sensu em Ciência Jurídica da UNIVALI, Itajaí, v.10, n.1, edição especial de 2015. Disponível em: www.univali.br/direitoepolitica - ISSN 1980-7791.

transição para a economia verde e a governança global do desenvolvimento sustentável."

Destacando Paulo Cruz e Zenildo Bodnar ${ }^{37}$ que foram basicamente três as propostas da conferência:

A primeira foi a de criar um novo organismo na ONU específico para a área ambiental. A segunda foi de dar ao PNUMA (Programa das Nações Unidas Para o Meio Ambiente) um novo status, igualando-o a organismos como a OMC (Organização Mundial do Comércio). A terceira proposta foi a de se promover a elevação do poder da Comissão de Desenvolvimento Sustentável da ONU.

Comenta Édis Milaré ${ }^{38}$ que o que aconteceu durante a Rio +20 foi que esta enfrentou a frieza do cenário internacional, sendo que o principal elemento da sua preparação foi o ceticismo da Cúpula dos Governos e, também, da Cúpula dos Povos. O Brasil era mais uma vez o anfitrião da grande conferência mundial, mas ainda possuía a condição de "emergente", deixando visíveis as dificuldades internas na preparação da Assembleia.

Desse modo, assim como a última Conferência, a sensação obtida após o término desta foi de fracasso em termo de avanços visíveis.

De todo exposto salienta-se que já na segunda conferência mundial se iniciaram as discussões sobre o princípio da sustentabilidade, tema primordial do presente artigo científico, tendo em vista este ser o objetivo primordial de busca de aplicabilidade. Portanto, importante é o destaque de considerações acerca de tal princípio e suas dimensões.

Nos dizeres de Denise Schmitt Siqueira Garcia $^{39}$, o termo sustentabilidade traz diversas conotações e "[...] decorre do conceito de sustentação, o qual, por sua

\footnotetext{
37 CRUZ, Paulo Márcio; BODNAR, Zenildo; participação especial Gabriel Real Ferrer. Globalização, transnacionalidade e sustentabilidade. - Dados eletrônicos. - Itajaí: UNIVALI, 2012. p. 169.

38 MILARÉ, Édis. Direito do Ambiente. 8. ed. São Paulo: RT, 2013. p. 1572.

39 GARCIA, Denise Schmitt Siqueira. A atividade portuária como garantidora do Princípio da Sustentabilidade. Revista Direito Econômico Socioambiental, Curitiba, v. 3, n. 2, p. 375-399, jul./dez. 2012. p. 389.
} 
GARCIA, Heloise Siqueira; BONISSONI, Natammy Luana de Aguiar. A democracia participativa como instrumento de alcance do princípio da sustentabilidade. Revista Eletrônica Direito e Política, Programa de Pós-Graduação Stricto Sensu em Ciência Jurídica da UNIVALI, Itajaí, v.10, n.1, edição especial de 2015. Disponível em: www.univali.br/direitoepolitica - ISSN 1980-7791.

vez, é aparentado à manutenção, conservação, permanência, continuidade e assim por diante."

Juarez Freitas ${ }^{40}$ conceitua o Princípio da Sustentabilidade como sendo um

[...] princípio constitucional que determina, com eficácia direta e imediata, a responsabilidade do Estado e da sociedade pela concretização direta e imediata, a responsabilidade do Estado e da sociedade pela concretização solidária do desenvolvimento material e imaterial, socialmente inclusivo, durável e equânime, ambientalmente limpo, inovador, ético e eficiente, no intuito de assegurar, preferencialmente de modo preventivo e precavido, no presente e no futuro, o direito ao bem-estar.

Resumindo, o mesmo autor mais adiante em sua obra, trata que a sustentabilidade suportaria, então, 10 elementos básicos: 1. É princípio constitucional de aplicação direta e imediata; 2. Reclama por resultados justos e não apenas efeitos jurídicos, ou seja, reclama por eficácia; 3. Em ligação à eficácia demanda eficiência; 4. Tem como objetivo tornar o ambiente limpo; 5. Pressupõe probidade nas relações públicas e privadas; 6. 7. 8. Implica prevenção, precaução e solidariedade intergeracional; 9. Implica no reconhecimento da responsabilidade solidária do Estado e da sociedade; e 10. Todos os demais elementos devem convergir para ideia de garantir um bemestar duradouro e multidimensional. ${ }^{41}$

Correlaciona-se por este viés, também, os ditames de Ramón Martín Mateo ${ }^{42}$, que tendo por base o Princípio da Sustentabilidade, considera que não se trata de instaurar uma espécie de utopia, senão sobre bases pragmáticas, que fará compatível o desenvolvimento econômico necessários para que nossos congêneres e seus descendentes possam viver dignamente com o respeito de um entorno biofísico adequado.

${ }^{40}$ FREITAS, Juarez. Sustentabilidade: direito ao futuro. 2. ed. Belo Horizonte: Fórum, 2012. p. 41.

${ }^{41}$ FREITAS, Juarez. Sustentabilidade: direito ao futuro. p. 50.

42 MARTÍN MATEO, Ramón. Manual de derecho ambiental. 2. ed. Madrid: Editorial Trivium, 1998. p. 41. 
GARCIA, Heloise Siqueira; BONISSONI, Natammy Luana de Aguiar. A democracia participativa como instrumento de alcance do princípio da sustentabilidade. Revista Eletrônica Direito e Política, Programa de Pós-Graduação Stricto Sensu em Ciência Jurídica da UNIVALI, Itajaí, v.10, n.1, edição especial de 2015. Disponível em: www.univali.br/direitoepolitica - ISSN 1980-7791.

Deve-se ainda ter em mente que, na realidade, a sustentabilidade é uma dimensão ética, trata de uma questão existencial, pois é algo que busca garantir a vida, não estando simplesmente relacionada à natureza, mas a toda uma relação entre indivíduo e todo o ambiente a sua volta. "Há uma relação complementar entre ambos. Aperfeiçoando o ambiente o homem aperfeiçoa a si mesmo." 43

Sendo nesse sentido que também comenta Gabriel Real Ferrer ${ }^{44}$

Sin embargo, la Sostenibilidad es una noción positiva y altamente proactiva que supone la introducción de los cambios necesarios para que la sociedad planetaria, constituida por la Humanidad, sea capaz de perpetuarse indefinidamente en el tiempo.

Dito isto, deve-se considerar o caráter pluridimensional da Sustentabilidade, conforme conceitua Juarez Freitas ${ }^{45}$, devendo aqui ser salientada a divergência presente na doutrina quanto à quantidade de dimensões que suportam a sustentabilidade, destacando-se, contudo, que majoritariamente considera-se a existência de três dimensões, chamadas de tripé da Sustentabilidade, que seriam: a dimensão ambiental, econômica e social.

Pela doutrina tradicional a sustentabilidade é tratada sob o viés destas três dimensões, todas integralmente correlatas e dependentes para a construção real da sustentabilidade. Porém, destaca-se a obra "Sustentabilidade: direito ao futuro" de Juarez Freitas ${ }^{46}$, o qual vai além, trazendo a concepção de mais duas dimensões, a compreender a ética e a jurídico-política, as quais, juntamente com

\footnotetext{
43 SOARES, Josemar; CRUZ, Paulo Márcio. Critério ético e sustentabilidade na sociedade pósmoderna: impactos nas dimensões econômicas, transnacionais e jurídicas. Revista Eletrônica Novos Estudos Jurídicos, ISSN Eletrônico 2175-0491, Itajaí, v. 17, n. 3, 30 quadrimestre de 2012. Disponível em: <http://siaiweb06.univali.br/seer/index.php/nej/article/view/4208> Acesso em 11 de novembro de 2013. p. 412.

44 REAL FERRER, Gabriel. Sostenibilidad, Transnacionalidad y Trasformaciones del Derecho. In: SOUZA, Maria Cláudia da Silva Antunes de; GARCIA, Denise Schmitt Siqueira (orgs.) Direito ambiental, transnacionalidade e sustentabilidade. - Dados eletrônicos. - Itajaí: UNIVALI, 2013. Disponível em: <www.univali.br/ppcj/ebooks> p. 13.

${ }^{45}$ FREITAS, Juarez. Sustentabilidade: direito ao futuro. p. 55.

${ }^{46}$ FREITAS, Juarez. Sustentabilidade: direito ao futuro.
} 
GARCIA, Heloise Siqueira; BONISSONI, Natammy Luana de Aguiar. A democracia participativa como instrumento de alcance do princípio da sustentabilidade. Revista Eletrônica Direito e Política, Programa de Pós-Graduação Stricto Sensu em Ciência Jurídica da UNIVALI, Itajaí, v.10, n.1, edição especial de 2015. Disponível em: www.univali.br/direitoepolitica - ISSN 1980-7791.

as três dimensões tradicionais, se tornam altamente correlatas e possibilitam a construção real da sustentabilidade.

Ademais, ainda salienta-se mais uma dimensão que aos poucos a doutrina está passando a aceitar a existência, chamada pelos Professores Paulo Márcio Cruz, Zenildo Bodnar e Gabriel Real Ferrer de dimensão tecnológica, a qual surge num contexto de evolução do homem ante os avanços da globalização, conforme destaca-se:

\begin{abstract}
A sustentabilidade foi inicialmente construída a partir de uma tríplice dimensão: ambiental, social e econômica. $\mathrm{Na}$ atual sociedade do conhecimento é imprescindível que também seja adicionada a dimensão tecnológica, pois é a inteligência humana individual e coletiva acumulada e multiplicada que poderá garantir um futuro sustentável. $\mathrm{Na}$ perspectiva jurídica todas estas dimensões apresentam identificação com a base de vários direitos humanos e fundamentais (meio ambiente, desenvolvimento, direitos prestacionais sociais, dentre outros), cada qual com as suas peculiaridades e riscos. ${ }^{47}$
\end{abstract}

Tal dimensão, conforme comenta o Professor Gabriel Real Ferrer ${ }^{48}$ é a que marcará as ações que possamos colocar em marchar para corrigir, se chegarmos a tempo, o rumo atual marcado pela catástrofe. Sem contar que a técnica também define e já definiu nossos modelos sociais, como a roda, as técnicas de navegação, a máquina a vapor, a eletricidade, o automóvel e a televisão, e nesse sentido, a internet, as nanotecnologias e o que se está por chegar também definirá.

Feito este adendo, destaca-se algumas das características principais de cada uma das dimensões, as tradicionalmente consideradas pela doutrina e as duas mais trazidas por Juarez Freitas, para que, então, possa-se passar à análise do foco principal do presente trabalho exposto no próximo item.

\footnotetext{
47 CRUZ, Paulo Márcio; BODNAR, Zenildo; participação especial Gabriel Real Ferrer. Globalização, transnacionalidade e sustentabilidade. p. 112.

48 REAL FERRER, Gabriel. Calidad de vida, medio ambiente, sostenibilidad y ciudadanía ¿Construimos juntos el futuro? Revista Eletrônica Novos Estudos Jurídicos, p. 319.
} 
GARCIA, Heloise Siqueira; BONISSONI, Natammy Luana de Aguiar. A democracia participativa como instrumento de alcance do princípio da sustentabilidade. Revista Eletrônica Direito e Política, Programa de Pós-Graduação Stricto Sensu em Ciência Jurídica da UNIVALI, Itajaí, v.10, n.1, edição especial de 2015. Disponível em: www.univali.br/direitoepolitica - ISSN 1980-7791.

A dimensão ambiental do Princípio da Sustentabilidade diz respeito à importância da proteção do meio ambiente e do Direito Ambiental, tendo como finalidade precípua garantir a sobrevivência do planeta através da preservação e melhora dos elementos físicos e químicos que a fazem possível, considerando sempre o alcance da melhor qualidade de vida do homem na terra. ${ }^{49}$

Ela prevê, basicamente, a consideração do direito das gerações atuais e futuras ao ambiente limpo em todos os seus aspectos. Nesse aspecto essa dimensão trata de abarcar, principalmente, as ideias de que não poderá haver qualidade de vida e longevidade digna em um ambiente degradado ou no limite, não se podendo ter, quiçá, a manutenção da vida humana, do que resulta o pensamento de que ou se protege a qualidade ambiental ou não se terá futuro para a espécie humana.

A dimensão econômica foca-se no desenvolvimento da economia com a finalidade de gerar melhor qualidade de vida às pessoas. Ele passou a ser considerada no contexto da sustentabilidade por dois motivos: 1 . Não haveria a possibilidade de retroceder nas conquistas econômicas de desenvolvimento alcançadas pela sociedade mundial; e 2. O desenvolvimento econômico estaria interligado com a dimensão social do Princípio da Sustentabilidade, pois ele é necessário para a diminuição da pobreza alarmante. ${ }^{50}$

Ela evoca o sopesamento entre a eficiência e a equidade, o que leva ao consequente sopesamento dos benefícios e custos diretos e indiretos (externalidades) dos empreendimentos públicos e privados, estando tudo isso intimamente ligado à ideia de medição das consequências a longo prazo. Desse modo, a sustentabilidade geraria uma nova economia, visada à reformulação de categorias e comportamentos que busquem o planejamento de longo prazo, a

49 GARCIA, Denise Schmitt Siqueira; GARCIA, Heloise Siqueira. Dimensão social do princípio da sustentabilidade: uma análise do mínimo existencial ecológico. In: SOUZA, Maria Claudia da Silva Antunes; GARCIA, Heloise Siqueira (org.) Lineamentos sobre sustentabilidade segundo Gabriel Real Ferrer - Dados eletrônicos. - Itajaí : UNIVALI, 2014. Disponível em: $<$ www.univali.br/ppcj/ebooks>, p. 44

50 GARCIA, Denise Schmitt Siqueira; GARCIA, Heloise Siqueira. Dimensão social do princípio da sustentabilidade: uma análise do mínimo existencial ecológico. In: SOUZA, Maria Claudia da Silva Antunes; GARCIA, Heloise Siqueira (org.) Lineamentos sobre sustentabilidade segundo Gabriel Real Ferrer, p. 44. 
GARCIA, Heloise Siqueira; BONISSONI, Natammy Luana de Aguiar. A democracia participativa como instrumento de alcance do princípio da sustentabilidade. Revista Eletrônica Direito e Política, Programa de Pós-Graduação Stricto Sensu em Ciência Jurídica da UNIVALI, Itajaí, v.10, n.1, edição especial de 2015. Disponível em: www.univali.br/direitoepolitica - ISSN 1980-7791.

ultrapassagem do culto excessivo dos bens posicionais e um sistema competente de incentivos. ${ }^{51}$

A dimensão social consiste no aspecto social relacionado às qualidades dos seres humanos, sendo também conhecida como capital humano. Ela está baseada num processo de melhoria na qualidade de vida da sociedade através da redução das discrepâncias entre a opulência e a miséria com o nivelamento do padrão de renda, o acesso à educação, à moradia, à alimentação. Estando, então, intimamente ligada à garantia dos Direitos Sociais, previstos no artigo $6^{\circ}$ da Carta Política Nacional, e da Dignidade da Pessoa Humana, princípio basilar da República Federativa do Brasil. ${ }^{52}$

Basicamente ela compreende o abrigo dos direitos fundamentais sociais, trazendo a ideia de que não se admite um modelo de desenvolvimento excludente e iníquo, lidando, deste modo, com a garantia da equidade intra e intergeracional, com a criação de condições para a potencialização das qualidades humanas através, principalmente, da garantia de educação de qualidade; e com o desenvolvimento do garantismo à dignidade de todos os seres presentes no planeta.

Considerando as dimensões trazidas por Juarez Freitas ${ }^{53}$ que ultrapassam as tradicionalmente tratadas, acima explanadas, tem-se a dimensão ética, a qual traz a ideia de que todos os seres possuem uma ligação intersubjetiva e natural, da qual segue a concepção da solidariedade como dever universalizável. A cooperação surgiria, então, como um dever evolutivo da espécie, favorável à continuidade da vida no sistema ambiental, sua busca primordial seria o da produção do bem-estar duradouro, com o reconhecimento da dignidade

\footnotetext{
${ }^{51}$ FREITAS, Juarez. Sustentabilidade: direito ao futuro, p. 65/67.

52 GARCIA, Denise Schmitt Siqueira; GARCIA, Heloise Siqueira. Dimensão social do princípio da sustentabilidade: uma análise do mínimo existencial ecológico. In: SOUZA, Maria Claudia da Silva Antunes; GARCIA, Heloise Siqueira (org.) Lineamentos sobre sustentabilidade segundo Gabriel Real Ferrer, p. 44/45.
}

${ }^{53}$ FREITAS, Juarez. Sustentabilidade: direito ao futuro, p. 55/75. 
GARCIA, Heloise Siqueira; BONISSONI, Natammy Luana de Aguiar. A democracia participativa como instrumento de alcance do princípio da sustentabilidade. Revista Eletrônica Direito e Política, Programa de Pós-Graduação Stricto Sensu em Ciência Jurídica da UNIVALI, Itajaí, v.10, n.1, edição especial de 2015. Disponível em: www.univali.br/direitoepolitica - ISSN 1980-7791.

intrínseca de todos os seres vivos, acima, assim, do antropocentrismo estrito, criando uma ética universal concretizável. ${ }^{54}$

E por fim, a dimensão jurídico-política, a qual estabelece que a sustentabilidade determina, independentemente de regulamentação, a tutela jurídica do direito ao futuro, apresentando-se como dever constitucional. A sustentabilidade é vista como princípio jurídico constitucional, imediata e diretamente vinculante, que altera a visão global do Direito, para o qual todos os esforços devem convergir, determinando a eficácia dos direitos fundamentais de todas as dimensões, fazendo com que seja tido como desproporcional e antijurídica toda e qualquer omissão causadora de injustos danos intra e intergeracionais. ${ }^{55}$

A partir da caracterização de cada uma dessas dimensões, deve-se sempre ter em mente que todas elas estão intimamente entrelaçadas de modo a proporcionar a visão da sustentabilidade como princípio-síntese que determina a proteção da própria vida humana na Terra.

A corroborar com a ideia primordial apresentada por Juarez Freitas ${ }^{56}$ de que o destino na espécie humana remanesce em suas próprias mãos, sendo, então, o motivo principal para escolher a sustentabilidade antes de tudo como oportunidade de assegurar para todas as gerações o direito fundamental ao futuro.

\section{A DEMOCRACIA PARTICIPATIVA COMO INSTRUMENTO DE ALCANCE DO PRINCÍPIO DA SUSTENTABILIDADE}

Após a breve apresentação acerca dos aspectos introdutórios relacionados à democracia, compete caracterizar o modelo mais abrangente de participação popular e, por consequência, um dos modelos mais democráticos de intervenção

\footnotetext{
${ }^{54}$ FREITAS, Juarez. Sustentabilidade: direito ao futuro, p. 60/64.

55 FREITAS, Juarez. Sustentabilidade: direito ao futuro, p. 67/71.

56 FREITAS, Juarez. Sustentabilidade: direito ao futuro.
} 
GARCIA, Heloise Siqueira; BONISSONI, Natammy Luana de Aguiar. A democracia participativa como instrumento de alcance do princípio da sustentabilidade. Revista Eletrônica Direito e Política, Programa de Pós-Graduação Stricto Sensu em Ciência Jurídica da UNIVALI, Itajaí, v.10, n.1, edição especial de 2015. Disponível em: www.univali.br/direitoepolitica - ISSN 1980-7791.

direta dos cidadãos nas tomadas de decisões e exercício do poder do Estado: a democracia participativa.

Para Norberto Bobbio ${ }^{57}$, a participação política pode se manifestar de diversas formas, ao exemplo do ato do voto, a militância num determinado partido político, a participação em manifestações, a discussão de acontecimentos políticos e até mesmo a difusão de informação política, entre outros. Desta forma, percebe-se que a participação ativa dos cidadãos está relacionada à atuação proativa da sociedade, onde a coletividade tem acesso aos seus representantes não somente durante o período de eleições, mas também tem a possibilidade de ser ouvida antes mesmo da tomada de decisões.

De igual forma, Daniela de Lima ${ }^{58}$ apresenta-se como favorável ao entendimento "que a verdadeira participação política deve ser entendida como uma atividade permanente de atuação e debate das questões políticas, locais ou não, exercida pelo cidadão $[\ldots]^{\prime \prime}$, tratando de maneira relevante a atuação regular e periódica do cidadão nas tomadas de decisões.

Com o advento da globalização e o crescimento acelerado pós Revolução Industrial, Paulo $\mathrm{Cruz}^{59}$ afirma que as sociedades cada vez mais diversificadas têm reduzido a relevância da democracia a um mero procedimento e, consequentemente, o grande valor e importância inserido nesta possibilidade de intervenção direta às tomadas de decisões estatais têm se perdido com o passar dos tempos.

De modo geral, os Doutores Paulo Márcio Cruz e Zenildo Bodnar através da obra "Globalização, Transnacionalidade e Sustentabilidade"60 apresentam a

57 BOBBIO, Norberto; MATTEUCCI, Nicola. PASQUINO, Gianfranco. Dicionário de Política. Tradução por Carmen C. Varriale, Gaetano Lo Mônaco, et al. 13. ed. Brasília: Editora UnB, 2010. p.888.

58 LIMA, Daniela de. Democracia e Estado no Século XXI: Debate sobre representação e participação. Itajaí: UNIVALI, 2013. p. 83. Dissertação (Mestrado). Programa de Pós-Graduação Stricto Sensu em Ciência Jurídica da Univali, Universidade do Vale do Itajaí, Itajaí, 2013.

59 CRUZ, Paulo Márcio; BODNAR, Zenildo. Globalização, Transnacionalidade e Sustentabilidade. p. 76.

60 LIMA, Daniela de. Democracia e Estado no Século XXI: Debate sobre representação e participação. p. 83. 
GARCIA, Heloise Siqueira; BONISSONI, Natammy Luana de Aguiar. A democracia participativa como instrumento de alcance do princípio da sustentabilidade. Revista Eletrônica Direito e Política, Programa de Pós-Graduação Stricto Sensu em Ciência Jurídica da UNIVALI, Itajaí, v.10, n.1, edição especial de 2015. Disponível em: www.univali.br/direitoepolitica - ISSN 1980-7791.

possibilidade de renovação desta concepção política no lugar de simplesmente eliminá-la, bem como adaptá-la às necessidades atuais.

Em linhas gerais, o presente artigo tem como finalidade apresentar a democracia participativa como instrumento de alcance e efetivação da sustentabilidade, partindo do pressuposto do aperfeiçoamento do atual conceito de democracia direta e sua adequação às temáticas atuais, possibilitando a construção de uma cultura política fundamentada em princípios sustentáveis.

É sobremodo importante destacar que para Gabriel Real Ferrer e Paulo Cruz" Democracia Participativa pode representar um estágio mais avançado do conceito de democracia. É a democracia como valor social e não apenas como procedimento."

Para desenvolver a caracterização da democracia participativa como pressuposto à sustentabilidade, o caráter pluridimensional da Sustentabilidade será tratado em conformidade à coexistência de suas dimensões principais e o englobamento da dimensão ética trazida por Juarez Freitas, enfocando, deste modo, nesta última, na dimensão social e na dimensão ambiental.

A conceituação apresentada por Juarez Freitas $^{62}$ remonta à dimensão ética uma conexão intrínseca com o princípio da Solidariedade trazendo como enfoque uma preocupação caracterizada pelo "dever universalizável de deixar o legado positivo na face da terra".

Da mesma forma, o renomado jurista menciona que tal percepção ética habita dentro de cada ser humano, "convindo que aqueles que possuem a maior autoconsciência assumam a tarefa de, sem encolher os ombros, resguardar a

60 CRUZ, Paulo Márcio; BODNAR, Zenildo. Globalização, Transnacionalidade e Sustentabilidade. p. 78.

${ }^{61}$ REAL FERRER, Gabriel; CRUZ, Paulo Márcio. Os novos cenários transnacionais e a democracia assimétrica. Revista de Estudos Constitucionais, Hermenêutica e Teoria do Direito. P. 96111 Julho-Dezembro de 2010. Disponível em <http://www.rechtd.unisinos.br/pdf/94.pdf>

${ }^{62}$ FREITAS, Juarez. Sustentabilidade: direito ao futuro. p. 60 
GARCIA, Heloise Siqueira; BONISSONI, Natammy Luana de Aguiar. A democracia participativa como instrumento de alcance do princípio da sustentabilidade. Revista Eletrônica Direito e Política, Programa de Pós-Graduação Stricto Sensu em Ciência Jurídica da UNIVALI, Itajaí, v.10, n.1, edição especial de 2015. Disponível em: www.univali.br/direitoepolitica - ISSN 1980-7791.

integridade e nobreza de caráter, de sorte a não permitir dano injusto por ação ou omissão"63.

Como claramente se vê, a tarefa a ser assumida por aqueles que têm a possibilidade de agir por meio de suas inserções em processos de discussão com o intuito o de efetivar sua participação democrática diretamente com a finalidade de também agir em favor daqueles não apresentam as mesmas condições de debate e participação.

Posto isso, a solidariedade é expressada como uma importante característica no processo democrático. Na mesma linha de raciocínio, observa Paulo Freire ${ }^{64}$ :

A Solidariedade Social de que precisamos para construir a sociedade menos feia e menos arestosa, em que podemos ser mais nós mesmos, tem na formação democrática uma prática de real importância. A aprendizagem da assunção do sujeito é incompatível com o treinamento pragmático ou com o elitismo autoritário dos que se pensam donos da verdade e do saber articulado.

Luiz Alberto Warat ${ }^{65}$ também é adepto a esta afirmação e ainda acrescenta:

É a solidariedade como forma de realização da cidadania, transitando-se do ato de dar esmola, como resposta ao individualismo possessivo (uma forma de altruísmo hipócrita), aos atos de participação solidária; enfim de uma modernidade de deveres absolutos ao início de um tempo de sentimentos autogestionados, reciprocamente gestionados no vínculo com o outro. É a cidadania como sentimento. É a ética do sentimento e da sensibilidade que não se impõe, não exige, e sim comove e motiva na comoção. É uma ética que moraliza a partir da emoção e da sensibilidade.

Portanto, percebe-se que não há como dissociar solidariedade de cidadania, consistindo a solidariedade num mecanismo para a configuração e efetivação da

\footnotetext{
${ }^{63}$ FREITAS, Juarez. Sustentabilidade: direito ao futuro. p. 61

${ }^{64}$ FREIRE, Paulo. Pedagogia da Autonomia: saberes necessários à prática educativa. São Paulo: Paz e Terra, 1996, p. 97

${ }^{65}$ WARAT, Luis Alberto. O ofício do mediador. Vol. I. Florianópolis: Habitus, 2001, p. 197-198.
} 
GARCIA, Heloise Siqueira; BONISSONI, Natammy Luana de Aguiar. A democracia participativa como instrumento de alcance do princípio da sustentabilidade. Revista Eletrônica Direito e Política, Programa de Pós-Graduação Stricto Sensu em Ciência Jurídica da UNIVALI, Itajaí, v.10, n.1, edição especial de 2015. Disponível em: www.univali.br/direitoepolitica - ISSN 1980-7791.

cidadania ${ }^{66}$, neste caso alcançada através da ativa cooperação para com o Estado por meio da democracia participativa.

A dimensão social da Sustentabilidade está essencialmente ligada à dimensão ética, tendo em vista aquela não cogitar a possibilidade de existência de uma sociedade excludente ou que possa aceitar qualquer tipo de discriminação. Portanto, considera-se de real importância a abrangência dos direitos fundamentais sociais na dimensão da sustentabilidade ${ }^{67}$ os quais necessitam de eficazes mecanismos que possam garantir sua eficiência e eficácia.

Atualmente, a questão da efetividade dos direitos humanos e fundamentais é debatida copiosamente em razão de que são inúmeros os tratados, declarações e até mesmo diversas constituições que apresentam direitos a serem resguardados pelo próprio Estado. Todavia, a maneira de implementá-los nos ordenamentos jurídicos internos de cada nação muitas vezes não é abordada pelos próprios documentos.

Nasce, portanto, mais uma oportunidade da democracia participativa interferir na consecução do alcance da Sustentabilidade. Dentro do ordenamento jurídico brasileiro, a Constituição da República Federativa do Brasil traz o possibilidade de apresentação de Iniciativa Popular como instrumento de democracia participativa. O artigo $61, \S 20$ da Constituição Republicana descreve a possibilidade de apresentação de proposta de Lei por iniciativa popular, a qual segue:

A iniciativa popular pode ser exercida pela apresentação à Câmara dos Deputados de projeto de lei subscrito por, no mínimo um por cento do eleitorado nacional, distribuído pelo menos por cinco Estados, com não menos de três décimos por cento dos eleitores de cada um deles. ${ }^{68}$

\footnotetext{
66 LIMA, Daniela de. Democracia e Estado no Século XXI: Debate sobre representação e participação. p. 92.

67 FREITAS, Juarez. Sustentabilidade: direito ao futuro. p. 59
}

68 BRASIL. Constituição da República Federativa do Brasil: promulgada em 5 de outubro de1988. Acesso em http://www.planalto.gov.br/ccivil_03/constituicao/constituicao.htm. Último acesso em 01/10/2014. 
GARCIA, Heloise Siqueira; BONISSONI, Natammy Luana de Aguiar. A democracia participativa como instrumento de alcance do princípio da sustentabilidade. Revista Eletrônica Direito e Política, Programa de Pós-Graduação Stricto Sensu em Ciência Jurídica da UNIVALI, Itajaí, v.10, n.1, edição especial de 2015. Disponível em: www.univali.br/direitoepolitica - ISSN 1980-7791.

Por conseguinte, como delineado acima, a sociedade reunida com uma mesma finalidade, atentando para os objetivos tanto de uma maioria como também de uma determinada minoria, podem, por meio da iniciativa popular, instrumento de democracia direta, alcançar a soberania popular.

Em suma, a sustentabilidade por meio de sua dimensão social pode incrementar a equidade intra e intergeracional, potencializar as condições propícias de florescimento das virtudes humanas, bem como pode apresentar uma sociedade mais apta à sobrevivência humana com respeito à dignidade aos demais seres vivos. ${ }^{69}$

Da mesma forma, a inserção conceitual de justiça pode ser inserida com o objetivo de que pode se considerar uma sociedade justa aquela que satisfaz as necessidades humanas básicas. Logo, impera absoluta a conclusão de que a justiça social pode ser compreendida como a satisfação de necessidades, preocupação esta que está intrinsicamente conectada à conceituação de sustentabilidade. ${ }^{70}$

Nesse contexto percebe-se que a diminuição das igualdades econômicas e sociais, um dos objetivos da dimensão social da sustentabilidade, está relacionada à intensidade da participação política do cidadão. ${ }^{71}$

Nesse enquadramento de ideias das dimensões da sustentabilidade, compete ressaltar a importância da dimensão ambiental ao presente estudo. Considerado fruto de dimensões históricas e culturais, o meio ambiente, que nos moldes do artigo $3^{0}$ da Lei $6938 / 8129^{72}$ é definido como o "conjunto de condições, leis, influências e interações de ordem física, química e biológica, que permite, abriga e rege a vida em todas as suas formas".

\footnotetext{
${ }^{69}$ FREITAS, Juarez. Sustentabilidade: direito ao futuro. p. 59

70 LENZI, Cristiano Luis. Democracia, justiça e cultura política da sustentabilidade. Disponível em: <http://www.educacao.salvador.ba.gov.br/site/documentos/espaco-virtual/espacoetica/WEBARTIGOS/democracia, $\% 20$ justica $\% 20 \mathrm{e} \% 2$ cultura $\% 20$ politica $\% 20$ de $\% 20$ sustentabilidad e.pdf>. Último acesso em 01/10/2014.
}

71 LIMA, Daniela de. Democracia e Estado no Século XXI: Debate sobre representação e participação. p. 83.

${ }^{72}$ BRASIL. Lei 6.938, de 31 de agosto de 1981. Brasília: Congresso Nacional, 1981. Disponível em: <http://www.planalto.gov.br/ccivil_03/leis/16938.htm>. 
GARCIA, Heloise Siqueira; BONISSONI, Natammy Luana de Aguiar. A democracia participativa como instrumento de alcance do princípio da sustentabilidade. Revista Eletrônica Direito e Política, Programa de Pós-Graduação Stricto Sensu em Ciência Jurídica da UNIVALI, Itajaí, v.10, n.1, edição especial de 2015. Disponível em: www.univali.br/direitoepolitica - ISSN 1980-7791.

Nestes moldes, percebe-se que o Meio Ambiente consiste em ser tratado como um direito humano fundamental, o qual caracteriza-se como direito de todos, bem de uso comum do povo e indispensável à qualidade de vida saudável. ${ }^{73}$ Ademais, o voto do Relator Ministro Celso de Mello na ADIN 3.540/DF31 foi claro no sentido de consagrar o direito ao meio ambiente ecologicamente equilibrado como direito fundamental, trazendo ao Estado e à coletividade a incumbência de defendê-lo e preservá-lo em benefício das presentes e futuras gerações. ${ }^{74}$

Seguindo o raciocínio de Tiago Fensterseifer ${ }^{75}$, o Estado Socioambiental de Direito ocasiona uma cidadania ambiental, a qual defende como característica o protagonismo da sociedade civil na proteção do ambiente. Ademais, correspondente ao exercício do Poder Público de amparo ecológico, com a finalidade de que o direito fundamental em questão seja resguardado da melhor maneira possível, é necessária a participação conjunta da sociedade civil.

Na mesma linha interpretativa o autor assevera:

Delimitado o papel central da democracia participativa no estado Socioambiental de Direito, pontua-se que esta se caracteriza por revitalizar e fortalecer o princípio democrático, que, com acerto, destaca Bonavides integrar o rol dos direitos fundamentais de quarta dimensão. Nas questões ambientais, o processo democrático deve estar sempre presente, tendo em vista a repercussão e a natureza coletiva da degradação ambiental para todo o conjunto da sociedade. ${ }^{76}$

Em vista disso, a democracia participativa deve ser respeitada como um mecanismo de fortalecimento do princípio democrático o qual, em se tratar de

${ }^{73}$ ANTUNES, Paulo Bessa. Direito Ambiental. 8. ed. Rio de Janeiro: Lumen Juris, 2005. p. 19 20.

74 BONISSONI, Natammy L. de Aguiar; DANTAS, Marcelo B.; FERRER, Gabriel Real. O Processo de internacionalização da proteção ambiental e dos direitos humanos. In: CRUZ, Paulo Márcio; DANTAS, Marcelo Buzaglo Danta (Org.) Direito e transnacionalização. Itajaí: UNIVALI, 2013.

75 FENSTERSEIFER, Tiago. Direitos fundamentais e proteção ambiental - A dimensão ecológica da dignidade humana no marco jurídico-constitucional do Estado Socioambiental de Direito. Porto Alegre: Livraria do Advogado Editora, 2008. p. 12.

76 FENSTERSEIFER, Tiago. Direitos fundamentais e proteção ambiental - A dimensão ecológica da dignidade humana no marco jurídico-constitucional do Estado Socioambiental de Direito. p. 122. 
GARCIA, Heloise Siqueira; BONISSONI, Natammy Luana de Aguiar. A democracia participativa como instrumento de alcance do princípio da sustentabilidade. Revista Eletrônica Direito e Política, Programa de Pós-Graduação Stricto Sensu em Ciência Jurídica da UNIVALI, Itajaí, v.10, n.1, edição especial de 2015. Disponível em: www.univali.br/direitoepolitica - ISSN 1980-7791.

Sustentabilidade deverá estar sempre presente tendo em vista as consequências da deterioração do meio ambiente atingirem toda a coletividade.

Além desses fatos, compete salientar que o modelo de democracia participativa não pressente tanto a participação direta no ato final de adoção de decisões políticas, mas conjectura a participação mais efetiva nos processos de decisão que posteriormente levam às decisões definitivas. Deste modo, a Democracia Participativa supõe, de uma parte, uma limitação do poder das organizações com incidência nas decisões políticas, e de outra parte, uma extensão dos direitos dos membros dessas organizações ou, se for o caso, do conjunto dos cidadãos, expressa em oportunidades de voz e garantias ao gozo de tais oportunidades. ${ }^{77}$

Por tudo isso, a sustentabilidade deve ser vista como um conceito relacionado a construção do futuro e a sua proteção em favor das futuras gerações. Tal fator indica a urgência de reformulação dos valores políticos atuais em razão do surgimento de novos ambientes transnacionais precisam ser supridos de maneira adequada às atuais demandas por participação. ${ }^{78}$

\section{CONSIDERAÇÕES FINAIS}

Por base de estudos da Teoria Política e da Filosofia, pode-se considerar a democracia, numa classificação tripartida clássica, como a forma de governo em que o povo, a coletividade, os cidadãos, é que possuem a titularidade do poder, caracterizando, nos tempos contemporâneos, apesar da possibilidade de percepção de suas diversas variações, pela necessária estreita relação entre Estado e Sociedade, através de vários mecanismos democráticos.

\footnotetext{
77 LIMA, Daniela de. Democracia e Estado no Século XXI: Debate sobre representação e participação. p. 83.

77 CRUZ, Paulo Márcio; BODNAR, Zenildo. Globalização, Transnacionalidade e Sustentabilidade. p. 92.

78 LIMA, Daniela de. Democracia e Estado no Século XXI: Debate sobre representação e participação. p. 83.
}

78 CRUZ, Paulo Márcio; BODNAR, Zenildo. Globalização, Transnacionalidade e Sustentabilidade. p. 75. 
GARCIA, Heloise Siqueira; BONISSONI, Natammy Luana de Aguiar. A democracia participativa como instrumento de alcance do princípio da sustentabilidade. Revista Eletrônica Direito e Política, Programa de Pós-Graduação Stricto Sensu em Ciência Jurídica da UNIVALI, Itajaí, v.10, n.1, edição especial de 2015. Disponível em: www.univali.br/direitoepolitica - ISSN 1980-7791.

Transportando-se do avanço da concepção teórica política da democracia e adentrando-se no Direito Ambiental, tem-se a consideração que este admite seu estudo a partir de vários enfoques, sendo que considerando o progresso cronológico e impulso político utilizou-se no presente trabalho as considerações estudadas pelo Professor Dr. Gabriel Real Ferrer, que separa o progresso cronológico em "ondas" em relação às grandes Conferências Mundiais sobre o Meio Ambiente. As quais, seguindo esta linha doutrinária, apresentam-se em quatro grandes momentos do cenário ambiental mundial: Primeira Conferência Mundial sobre Meio Ambiente, ocorrida em 1972 em Estocolmo; Segunda Conferência Mundial sobre Meio Ambiente, ocorrida em 1992, sediada na cidade do Rio de Janeiro; Conferência Mundial sobre o Meio Ambiente de 2002, ocorrida em Johannesburg, também conhecida como Rio +10; e Conferência Mundial sobre o Meio Ambiente, ocorrida no ano de 2012, novamente na cidade do Rio de Janeiro, conhecida como Rio +20 .

As discussões nesse âmbito a respeito do Princípio da Sustentabilidade, tema primordial do presente artigo científico, tendo em vista este ser o objetivo principal de busca de aplicabilidade, iniciaram-se, então, na segunda conferência mundial e vêm se desenrolando até o presente momento.

A Sustentabilidade numa visão geral, concatenando as ideias conceituais dos principais doutrinadores da área trabalhados no presente artigo, possui, em realidade, uma concepção acima de tudo ética, que trata de uma questão existencial, pois é algo que busca garantir a vida, não estando simplesmente relacionada à natureza, mas a toda uma relação entre indivíduo e todo o ambiente a sua volta.

Tal Princípio, de abrangência indiscutível, deve ser sempre considerado de caráter pluridimensional, ou seja, que comporta diversas dimensões diretamente interligadas que a eles estão correlacionadas. Conforme apresentado, há divergência doutrinária quanto à quantidade de dimensões que suportam a sustentabilidade, destacando-se, contudo, que majoritariamente considera-se a existência de três dimensões, chamadas de tripé da Sustentabilidade, que seriam: a dimensão ambiental, econômica e social. Porém, destaca-se que o 
GARCIA, Heloise Siqueira; BONISSONI, Natammy Luana de Aguiar. A democracia participativa como instrumento de alcance do princípio da sustentabilidade. Revista Eletrônica Direito e Política, Programa de Pós-Graduação Stricto Sensu em Ciência Jurídica da UNIVALI, Itajaí, v.10, n.1, edição especial de 2015. Disponível em: www.univali.br/direitoepolitica - ISSN 1980-7791.

doutrinador Juarez Freitas vai além, trazendo a concepção de mais duas dimensões, a compreender a ética e a jurídico-política. Ademais, ainda salientase mais uma dimensão que aos poucos a doutrina está passando a aceitar a existência, chamada pelos Professores Paulo Márcio Cruz, Zenildo Bodnar e Gabriel Real Ferrer de dimensão tecnológica, a qual surge num contexto de evolução do homem ante os avanços da globalização.

A partir da caracterização de cada uma dessas dimensões, deve-se sempre ter em mente que todas elas estão intimamente entrelaçadas de modo a proporcionar a visão da sustentabilidade como princípio-síntese que determina a proteção da própria vida humana na Terra.

Relacionando, então, os aspectos introdutórios referentes à democracia, necessária foi a caracterização do modelo mais abrangente de participação popular, e, consequentemente, mais democrático, de intervenção direta dos cidadãos nas tomadas de decisões e exercício do poder do Estado, que é a democracia participativa, também enfoque principal do presente estudo, que se relacionará com o acima apresentado.

A participação ativa dos cidadãos está relacionada à atuação proativa da sociedade, onde a coletividade tem acesso aos seus representantes não somente durante o período de eleições, mas também tem a possibilidade de ser ouvida antes mesmo da tomada de decisões. Paulo Cruz afirma que as sociedades cada vez mais diversificadas têm reduzido a relevância da democracia a um mero procedimento e, consequentemente, o grande valor e importância inserido nesta possibilidade de intervenção direta às tomadas de decisões estatais têm se perdido com o passar dos tempos.

Conforme este mesmo doutrinador em estudo conjunto com Gabriel Real Ferrer, a democracia participativa estaria representando um estágio mais avançado do conceito de democracia, colocando-a como valor social e não apenas como procedimento.

O presente artigo teve como finalidade apresentar a democracia participativa como instrumento de alcance e efetivação da sustentabilidade, partindo do 
GARCIA, Heloise Siqueira; BONISSONI, Natammy Luana de Aguiar. A democracia participativa como instrumento de alcance do princípio da sustentabilidade. Revista Eletrônica Direito e Política, Programa de Pós-Graduação Stricto Sensu em Ciência Jurídica da UNIVALI, Itajaí, v.10, n.1, edição especial de 2015. Disponível em: www.univali.br/direitoepolitica - ISSN 1980-7791.

pressuposto do aperfeiçoamento do atual conceito de democracia direta e sua adequação às temáticas atuais, possibilitando a construção de uma cultura política fundamentada em princípios sustentáveis.

Em vista disso, a democracia participativa deve ser respeitada como um mecanismo de fortalecimento do princípio democrático o qual, em se tratar de Sustentabilidade deverá estar sempre presente tendo em vista as consequências da deterioração do meio ambiente atingir toda a coletividade. Por tudo isso, a sustentabilidade deve ser vista como um conceito relacionado à construção do futuro e à sua proteção em favor das futuras gerações. Tal fator indica a urgência de reformulação dos valores políticos atuais em razão do surgimento de novos ambientes transnacionais, os quais precisam ser supridos de maneira adequada às atuais demandas por participação.

\section{REFERÊNCIAS DAS FONTES CITADAS}

ANTUNES, Paulo Bessa. Direito Ambiental. 8. ed. Rio de Janeiro: Lumen Juris, 2005.

ARISTÓTELES. Política. 5. ed. Texto integral. Tradução de Pedro Constantin Tolens. São Paulo: Martin Claret, 2001.

BOBBIO, Norberto. Estado, governo, sociedade. Para uma teoria geral da política. 10. ed. Tradução de Marco Aurélio Nogueira. São Paulo: Editora Paz e Terra, 2003.

. Liberalismo e democracia. 3. ed. Tradução de Marco Aurélio Nogueira. São Paulo: Brasiliense, 1990.

O futuro da democracia. 9. ed. Tradução de Marco Aurélio Nogueira. São Paulo: Editora Paz e Terra, 2004.

; MATTEUCCI, Nicola. PASQUINO, Gianfranco. Dicionário de Política. Tradução por Carmen C. Varriale, Gaetano Lo Mônaco, et al. 13. ed. Brasília: Editora UnB, 2010.

BONAVIDES, Paulo. Ciência política. 18. ed. São Paulo: Malheiros, 2011.

BONISSONI, Natammy L. de Aguiar; DANTAS, Marcelo B.; FERRER, Gabriel Real. O Processo de internacionalização da proteção ambiental e dos direitos humanos. In: CRUZ, Paulo Márcio; DANTAS, Marcelo Buzaglo Danta (Org.) Direito e transnacionalização. Itajaí: UNIVALI, 2013. 
GARCIA, Heloise Siqueira; BONISSONI, Natammy Luana de Aguiar. A democracia participativa como instrumento de alcance do princípio da sustentabilidade. Revista Eletrônica Direito e Política, Programa de Pós-Graduação Stricto Sensu em Ciência Jurídica da UNIVALI, Itajaí, v.10, n.1, edição especial de 2015. Disponível em: www.univali.br/direitoepolitica - ISSN 1980-7791.

BRASIL. Constituição da República Federativa do Brasil: promulgada em 5 de outubro de1988. Acesso em http://www.planalto.gov.br/ccivil_03/constituicao/constituicao.htm. Último acesso em 01/10/2014.

Lei 6.938, de 31 de agosto de 1981. Brasília: Congresso Nacional, 1981. Disponível em: <http://www.planalto.gov.br/ccivil_03/leis/l6938.htm>.

CRUZ, Paulo Márcio. Democracia e cidadania. Revista Eletrônica Novos Estudos Jurídicos, ISSN Eletrônico 2175-0491, Itajaí, v. 5, n. 10, 2000. Disponível em:

http://siaiweb06.univali.br/seer/index.php/nej/article/view/1539>.

; BODNAR, Zenildo; participação especial Gabriel Real Ferrer. Globalização, transnacionalidade e sustentabilidade. - Dados eletrônicos. Itajaí: UNIVALI, 2012. Disponível em: <www.univali.br/ppcj/ebooks>.

FENSTERSEIFER, Tiago. Direitos fundamentais e proteção ambiental - A dimensão ecológica da dignidade humana no marco jurídico-constitucional do Estado Socioambiental de Direito. Porto Alegre: Livraria do Advogado Editora, 2008.

FREIRE, Paulo. Pedagogia da Autonomia: saberes necessários à prática educativa. São Paulo: Paz e Terra, 1996.

FREITAS, Juarez. Sustentabilidade: direito ao futuro. 2. ed. Belo Horizonte: Fórum, 2012.

GARCIA, Denise Schmitt Siqueira. A atividade portuária como garantidora do Princípio da Sustentabilidade. Revista Direito Econômico Socioambiental, Curitiba, v. 3, n. 2, p. 375-399, jul./dez. 2012.

; GARCIA, Heloise Siqueira. Dimensão social do princípio da sustentabilidade: uma análise do mínimo existencial ecológico. In: SOUZA, Maria Claudia da Silva Antunes; GARCIA, Heloise Siqueira (org.) Lineamentos sobre sustentabilidade segundo Gabriel Real Ferrer - Dados eletrônicos. - Itajaí: UNIVALI, 2014. Disponível em: <www.univali.br/ppcj/ebooks>

Democracia e solidariedade: a solidariedade como instrumento de busca de uma sociedade democrática. In: MACHADO, Edinilson Donisete; BERTASO, João Martins; CUNHA, Leandro Reinaldo da. (coord.) Direitos fundamentais e

democracia III. Florianópolis: CONPEDI, 2014. Disponível em: <http://publicadireito.com.br/publicacao/ufsc/ficha/211.pdf>. Acesso em: 30 de setembro de 2014. p. 162/178.

KELSEN, Hans. Teoria geral do direito e do Estado. 4. ed. Tradução de Luís Carlos Borges. São Paulo: Martins Fontes, 2005.

LENZI, Cristiano Luis. Democracia, justiça e cultura política da sustentabilidade. Disponível

em 
GARCIA, Heloise Siqueira; BONISSONI, Natammy Luana de Aguiar. A democracia participativa como instrumento de alcance do princípio da sustentabilidade. Revista Eletrônica Direito e Política, Programa de Pós-Graduação Stricto Sensu em Ciência Jurídica da UNIVALI, Itajaí, v.10, n.1, edição especial de 2015. Disponível em: www.univali.br/direitoepolitica - ISSN 1980-7791.

<http://www.educacao.salvador.ba.gov.br/site/documentos/espacovirtual/espacoetica/WEBARTIGOS/democracia, \%20justica $\% 20 \mathrm{e} \% 20$ cultura\%20politica\%20de $\% 20$ sustentabilidade.pdf. > Último acesso em 01/10/2014.

LIMA, Daniela de. Democracia e Estado no Século XXI: Debate sobre representação e participação. Itajaí: UNIVALI, 2013. p. 83. Dissertação (Mestrado). Programa de Pós-Graduação Stricto Sensu em Ciência Jurídica da Univali, Universidade do Vale do Itajaí, Itajaí, 2013.

LOCKE, John. Segundo tratado sobre o governo. Texto integral. Tradução de Alex Marins. São Paulo: Martin Claret, 2002.

MARTÍN MATEO, Ramón. Manual de derecho ambiental. 2. ed. Madrid: Editorial Trivium, 1998.

MIGLINO, Arnaldo. A cor da democracia. Florianópolis: Conceito editorial, 2010.

MILARÉ, Édis. Direito do Ambiente. 8. ed. São Paulo: RT, 2013.

MONTESQUIEU. Do espírito das leis. Texto integral. Tradução de Jean Melville. São Paulo: Martin Claret, 2002.

PLATÃO. A república. Texto integral. Tradução de Pietro Nassetti. São Paulo: Martin Claret, 2003.

REAL FERRER, Gabriel. Calidad de vida, medio ambiente, sostenibilidad y ciudadanía ¿Construimos juntos el futuro? Revista Eletrônica Novos Estudos Jurídicos, ISSN Eletrônico 2175-0491, Itajaí, v. 17, n. 3, 30 quadrimestre de $2012 . \quad$ Disponível em: <http://siaiweb06.univali.br/seer/index.php/nej/article/view/4202>.

- La construcción del Derecho Ambiental. Revista Aranzadi de derecho ambiental, Pamplona - España, n. 1, 2002. p. 73-93.

La construcción del derecho ambiental. Revista Eletrônica Direito e Política, Programa de Pós-Graduação Stricto Sensu em Ciência Jurídica da UNIVALI, Itajaí, v.6, n.2, $2^{0}$ quadrimestre de 2011. Disponível em: $<$ www.univali.br/direitoepolitica > - ISSN 1980-7791.

Sostenibilidad, Transnacionalidad y Trasformaciones del Derecho. In: SOUZA, Maria Cláudia da Silva Antunes de; GARCIA, Denise Schmitt Siqueira (orgs.) Direito ambiental, transnacionalidade e sustentabilidade. - Dados eletrônicos. - Itajaí: UNIVALI, 2013. Disponível em: $<$ www.univali.br/ppcj/ebooks>.

; CRUZ, Paulo Márcio. Os novos cenários transnacionais e a democracia assimétrica. Revista de Estudos Constitucionais, Hermenêutica e Teoria do 
GARCIA, Heloise Siqueira; BONISSONI, Natammy Luana de Aguiar. A democracia participativa como instrumento de alcance do princípio da sustentabilidade. Revista Eletrônica Direito e Política, Programa de Pós-Graduação Stricto Sensu em Ciência Jurídica da UNIVALI, Itajaí, v.10, n.1, edição especial de 2015. Disponível em: www.univali.br/direitoepolitica - ISSN 1980-7791.

Direito. P. 96-111 Julho-Dezembro de 2010. Disponível em <http://www.rechtd.unisinos.br/pdf/94.pdf>.

ROUSSEAU, Jean-Jacques. Do contrato social. - Dados eletrônicos. Florianópolis: UFSC - Centro de filosofia e ciências humanas. Edição eletrônica: Ridendo Castigat Mores. Disponível em: <http://www.cfh.ufsc.br/ wfil/contrato.pdf> Acesso em 25 de novembro de 2013.

SOARES, Josemar; CRUZ, Paulo Márcio. Critério ético e sustentabilidade na sociedade pós-moderna: impactos nas dimensões econômicas, transnacionais e jurídicas. Revista Eletrônica Novos Estudos Jurídicos, ISSN Eletrônico 21750491, Itajaí, v. 17, n. 3, 30 quadrimestre de 2012. Disponível em: <http://siaiweb06.univali.br/seer/index.php/nej/article/view/4208> Acesso em 11 de novembro de 2013.

VIEIRA, Ricardo Stanziola. Rio+20 - conferência das nações unidas sobre meio ambiente e desenvolvimento: contexto, principais temas e expectativas em relação ao novo "direito da sustentabilidade". Revista Eletrônica Novos Estudos Jurídicos, ISSN Eletrônico 2175-0491, Itajaí, v. 17, n. 1, 10 quadrimestre de $2012 . \quad$ Disponível em: <http://siaiweb06.univali.br/seer/index.php/nej/article/view/3638>.

WARAT, Luis Alberto. O ofício do mediador. Vol. I. Florianópolis: Habitus, 2001.

Submetido em: Outubro/2014

Aprovado em: Outubro/2014 